\title{
PENGEMBANGAN LEMBAR KERJA PESERTA DIDIK BERBASIS PROBLEM BASED LEARNING PADA MATERI IKATAN KIMIA KELAS X
}

\author{
Yuliandriati ${ }^{1^{*}, \text { Susilawati }^{2} \text { dan Rozalinda }}{ }^{2}$ \\ ${ }^{1}$ Program Studi Magister Pendidikan Kimia, FKIP, Universitas Riau, Jl. H. R. Soebrantas Km \\ 12,5 Panam, Pekanbaru, 28293, Indonesia \\ ${ }^{2}$ Universitas Riau, Jl. H. R. Soebrantas Km 12,5 Panam, Pekanbaru, 28293, Indonesia \\ *E-mail: yuliandriatispd2@gmail.com
}

\begin{abstract}
ABSTRAK
Penelitian ini bertujuan untuk menghasilkan bahan ajar berupa Lembar Kerja Peserta Didik yang valid, sehingga dapat dinyatakan layak untuk digunakan dalam pembelajaran. Jenis penelitian ini adalah penelitian dan pengembangan (Research and Development) dengan rancangan penelitian menggunakan pengembangan model Borg and Gall. Objek penelitian adalah LKPD berbasis PBL. Instrumen pengumpulan data yang digunakan adalah lembar validasi, angket respon pendidik dan angket respon peserta didik. Teknik pengumpulan data yaitu lembar validasi, angket respon tiga orang pendidik dan angket respon peserta didik untuk melihat LKPD. Teknik analisis data yang digunakan adalah analisis deskriptif kualitatif yang bertujuan untuk mendeskripsikan hasil validitas yang diberikan validator, hasil angket respon pendidik dan peserta yaitu dengan cara menghitung persentase nilai validasi, angket respon pendidik dan angket respon peserta didik. Hasil analisis data diperoleh validitas pada aspek isi, aspek penyajian, aspek bahasa, aspek kegrafisan, karakteristik Problem Based Learning dan berturut-turut sebesar 98,3\%, 98,3\%, 93,3\%, 95,8\% dan 100\% dengan katagori valid. Hasil uji respon pendidik dan peserta didik sebagai pengguna terhadap LKPD berturut-turut sebesar 95,8\%dan 96,13\%. Berdasarkan hasil analisis data dapat disimpulkan bahwa LKPD berbasis PBL pada materi ikatan kimia yang dikembangkan dinyatakan valid dan layak untuk digunakan dalam kegiatan pembelajaran.
\end{abstract}

Kata kunci: ikatan kimia, lembaran kegiatan peserta didik (LKPD), problem based learning

\begin{abstract}
The purpose of the research is to produce valid teaching materials in the form of valid student activity sheets (LKPD), so that it can be considered feasible to be used in learning. Method used in this research was Research and Development with the development process referring to the development model of Borg and Gall. The object of research is Problem Based Learning (PBL) LKPD. The data collection instruments used were in the form of validation sheets and educator's response questionnaires. The technique of data collection is by using validation of the three validators' and educators' questionnaires responses to see the practicality of the LKPD. The technique of data analysis is descriptive qualitative analysis which aims to describe the results of the validity provided by the validator, the results of the questionnaire of educator and students was obtained by calculating the percent value of validity from educator response questionnaire and student response questionnaire. The validity results
\end{abstract}


from data analysis on aspects of content, presentation aspects, language aspects, graphic aspects, characteristics of Problem Based Learning were 98.3\%, 98.3\%, 93.3\%, 95.8\% and 100\% respectively. The test results of the response of educators and students as users of LKPD were $95.8 \%$ and $96.13 \%$ respectively. Based on the results of data analysis it can be concluded that the LKPD developed by using Problem Based Learning in Chemical bond Material is declared valid and suitable to be used in learning activities.

Keywords: chemical bonds, student activity sheets (LKPD), problem based learning.

DOI: https://doi.org/10.15575/jtk.v4i1.4231

\section{PENDAHULUAN}

Kurikulum yang digunakan dan diberlakukan di Indonesia saat ini adalah kurikulum 2013. Kurikulum 2013 merupakan kurikulum yang menuntut kemandirian, tanggung jawab dan karakter dari siswa. Hampir seluruh model pembelajaran yang ada pada kurikulum 2013, berpusat pada siswa sebagai pemeran utama dalam pendidikan (Kemendikbud, 2013). Berdasarkan kurikulum 2013 mata pelajaran kimia merupakan salah satu mata pelajaran peminatan di Sekolah Menengah Atas (SMA)/MA (Madrasah Aliyah). Ilmu kimia merupakan salah satu cabang ilmu pengetahuan alam (IPA) yang memiliki peran sejajar dengan cabang-cabang IPA lainnya, seperti fisika, biologi, geologi, dan astronomi.

Salah satu mata pelajaran IPA yang kurang diminati peserta didik di SMA adalah mata pelajaran kimia. Hal ini disebabkan karena 1) pada bangku Sekolah Menengah Pertama (SMP) pembelajaran kimia belum diajar secara terpisah tetapi masih bergabung dengan pembelajaran fisika sehingga peserta didik belum terlalu mengenal pembelajaran kimia tersebut; 2) pembelajaran kimia yang disajikan di dalam buku paket tidak lepas dari tuntutan kurikulum namun di dalam buku paket tersebut yang diubah hanyalah susunan penyajian materi saja padahal belum memenuhi tuntutan kurikulum; 3) bagaimana seorang pendidik mengajarkan pembelajaran kimia di kelas; 4) informasi yang diterima peserta didik; 5) sasaran dan tujuan peserta didik dalam mempelajari pembelajaran kimia. Untuk menambahkan minat peserta didik terhadap pembelajaran kimia dapat dilakukan dengan cara 1) mengubah dan membangun cara berpikir peserta didik dengan cara menjelaskan bahwa kimia itu penting, menyehatkan, menyejahterakan, menyenangkan dan bermanfaat; 2) setiap materi pembelajaran kimia di SMA harus dihubungkan dan dikaitkan dengan fenomena kimia dalam kehidupan sehari hari sehingga dapat melatih peserta didik untuk berpikir kritis dan kreatif dalam menyelesaikan berbagai masalah kimia dalam kehidupan sehari hari sesuai dengan tujuan pembelajaran kimia menurut Kemendikbud. Salah satu tujuan pembelajaran kimia SMA menurut Kemendikbud (2013) adalah peserta didik dapat menanamkan dan menerapkan konsepkonsep kimia dalam menyelesaikan permasalahan kehidupan sehari-hari dan teknologi. Materi yang diajarkan dalam ilmu kimia sebagian bersifat "kasat mata" (visible), dan sebagian lagi bersifat abstrak atau "tidak kasat mata"(invisible) (Tim Penyusun, 2006).

Beberapa hasil penelitian terdahulu menyatakan bahwa mata pelajaran kimia merupakan mata pelajaran yang dianggap sulit (Cardellini, 2012), tidak menyenangkan dan tidak menarik bagi peserta didik untuk dipelajari (Chun Wu \& Jordan, 2010), serta 
peserta didik kesulitan dalam memahami materi kimia yang konsepnya bersifat abstrak (Alfatie, 2009). Materi kimia yang bersifat abstrak sulit untuk dipahami peserta didik, sehingga peserta didik kurang memahami konsep-konsep kimia. Konsep kimia yang abstrak merupakan penjelasan bagi konsep kimia yang konkret. Karakteristik kimia yang secara umum bersifat abstrak menjadi salah satu faktor peserta didik menganggap kimia sulit untuk dipahami (Marsita dkk, 2011). Anggapan-anggapan negatif mengenai pembelajaran kimia tersebut cenderung akan menimbulkan kesulitan belajar dan berimplikasi pada kualitas dan hasil belajar yang buruk.

Salah satu hal yang mempengaruhi kualitas pembelajaran kimia di kelas adalah lemahnya proses pembelajaran dan kesiapan pendidik sebelum proses pembelajaran. Suatu kegiatan belajar mengajar yang di dalamnya terdapat interaksi atau hubungan antara pendidik dengan peserta didik serta komunikasi timbal balik yang berlangsung dalam situasi edukatif untuk mencapai tujuan pembelajaran disebut dengan proses pembelajaran. Syarat utama berlangsungnya proses pembelajaran adalah adanya hubungan timbal balik antara pendidik dengan peserta didik. Segala sesuatu yang harus dipersiapkan pendidik sebelum proses pembelajaran dimulai adalah perangkat pembelajaran seperti Lembaran Kegiatan Peserta Didik atau disingkat dengan LKPD yang sebelum Kurikulum 2013 disebut dengan LKS. LKPD yang lengkap akan membantu pendidik dan peserta didik dalam proses belajar. LKPD merupakan salah satu perangkat pembelajaran yang harus dimiliki dan dirancang oleh pendidik karena dengan adanya LKPD akan membantu dan mempermudah pendidik melaksanakan pembelajaran dan membantu peserta didik dalam menyelesaikan tugas pembelajaran secara mandiri sesuai dengan pendapat
Kawiyah (2015) bahwa perangkat pembelajaran yang dilekapi dengan LKPD (cetak atau non cetak) dan RPP dapat memudahkan guru dalam melaksanakan pembelajaran dan memudahkan peserta didik untuk belajar secara mandiri.

Chappell \& Craft (2009) dan Susantini et al. (2016) menyatakan bahwa lembar kerja siswa adalah bagian dari bahan ajar yang dapat digunakan untuk mengembangkan keterampilan berpikir, bertanya dan menjawab pertanyaan, membuat koneksi dan menilai peningkatan hasil belajar siswa. Tomlinson (2012) menyatakan bahwa bahan ajar dan lembar kerja yang dapat mengembangkan pengalaman belajar peserta didik adalah perangkat yang: informatif (menginformasikan tujuan pembelajaran), ada strategi pembelajaran (untuk pembelajaran tatap muka dan praktik), merumuskan dengan jelas pengalaman belajar, motivasi, eksplorasi untuk membantu peserta didik melakukan penemuan baru dalam penelitian bahwa bahan ajar dan lembar kerja yang ideal adalah perangkat yang dapat memberikan. Selain itu, Richard (2001) dan Tomlinson (2012) menyatakan informasi dan pengalaman belajar dan dikembangkan dengan desain dan fitur yang baik.

Saat ini proses pembelajaran yang berlangsung belum efektif dan peserta didik belum terlibat secara aktif dalam mengembangkan pengetahuannya karena kegiatan pembelajaran masih berpusat pada pendidik. Untuk mengatasi hal tersebut dibutuhkan bahan ajar yang tepat berupa LKPD. Perangkat pembelajaran atau bahan ajar yang dapat mendukung proses pembelajaran dan mengarahkan proses belajar peserta didik serta mempermudah peserta didik memahami konsep kimia yang bersifat abstrak adalah LKPD atau Lembaran Kegiatan Peserta Didik. Dalam proses pembelajaran (PBM) LKPD sudah ada sejak 
dahulunya atau sebelum diberlakukan kurikulum 2013 tetapi LKPD tersebut belum dapat memberdayakan peserta didik untuk belajar mandiri, belum dapat meningkatkan kemampuan berpikir kritis dan belum dapat memecahkan masalah.

Hasil observasi dan wawancara terhadap salah seorang pendidik di SMA Negeri 1 Bangkinang Kota menunjukkan bahwa hasil belajar siswa khususnya pada materi ikatan kimia pada tahun ajaran 2017/2018 masih tergolong rendah, yaitu hanya sekitar $30-40 \%$ dari 34 orang jumlah siswa yang mampu mencapai nilai ketuntasan klasikal. Kemudian untuk mengetahui apa sebenarnya faktor penyebab rendahnya hasil belajar kimia siswa, peneliti mencoba untuk mengobservasi secara langsung bagaimana proses kegiatan pembelajaran di ruang kelas. Ternyata dalam kegiatan pembelajaran, pembelajaran masih berpusat pada pendidik, program dan LKPD yang digunakan belum sesuai dengan tuntutan Kurikulum 2013, RPP dan LKPD belum tervalidasi dengan baik dan belum sesuai dengan tututan Kurikulum 2013. Beberapa pendidik di sekolah masih mengandalkan LKPD terbitan penerbit yang di dalamnya terdapat rangkuman materi dan soal-soal latihan serta rumus-rumus yang belum tersaji dengan menarik sehingga membuat peserta didik menjadi kurang aktif pada saat pembelajaran berlangsung.

Di beberapa sekolah sangat sulit ditemukan LKPD yang sifatnya 1) meningkatkan aktivitas belajar peserta didik; 2) LKPD yang lebih mengaktifkan peranan peserta didik ketimbang pendidik; 3) LKPD yang sifatnya mengembangkan kreaktivitas berpikir peserta didik dalam memecahkan berbagai permasalahan yang berhubungan dengan kehidupan sehari; 4) LKPD yang membimbing dan mengarahkan serta memberdayakan peserta didik untuk belajar mandiri, meningkatkan kemampuan berpikir kritis, dan meningkatkan kemampuan untuk belajar secara kolaboratif dalam sebuah tim dan dengan orang lain. LKPD yang banyak beredar dan yang digunakan di sekolah adalah LKPD yang disusun dan dirancang oleh beberapa penerbit yang di dalamnya terdapat rangkuman materi dan soal-soal latihan serta rumus-rumus yang belum tersaji dengan menarik yang berefek terhadap hasil belajar peserta didik. Selain dari itu soal-soal yang ada di dalam LKPD memiliki soal yang kurang variatif di mana peserta didik hanya diminta untuk mengisi titik-titik atau menjawab soal pilihan ganda sehingga tidak mampu memicu peserta didik untuk aktif dan berpikir tingkat tinggi.

Peneliti melakukan analisis terhadap LKPD yang banyak digunakan dengan hasil analisis yakni 1) soal soal yang ada di dalam LKPD belum menanamkan konsep dari materi dan kurang variatif di mana peserta didik hanya diminta mengisi titik-titik atau menjawab soal pilihan ganda; 2) konten atau isi dari LKPD belum sesuai dengan materi yang ada pada buku ajar; 3) kegiatan yang terdapat di dalam RPP belum sesuai dengan LKPD yang digunakan, terutama pada langkah-langkah pembelajaran; 4) LKPD belum menggunakan model pembelajaran yang dianjurkan oleh Kementerian Pendidikan Nasional; 5) LKPD yang digunakan belum melatih kemampuan peserta didik dalam pemecahan masalah dan belum dapat meningkatkan kemampuan untuk belajar secara kolaboratif dalam sebuah tim dan dengan orang lain

Sebaiknya isi LKPD disesuaikan dengan kompetensi dasar yang ada di dalam kurikulum dan indikator pembelajaran serta dirancang dan dikembangkan oleh pendidik sesuai dengan pendapat Lestari Majid (2013) bahwa LKPD yang baik sebaiknya dibuat dan didesain oleh pendidik dan disesuaikan

This is an open access article under CC-BY-SA license (https://creativecommons.org/licenses/by-sa/4.0/) 
dengan kompetensi dasar, pokok bahasan, indikator pembelajaran dan tujuan pembelajaran yang akan dicapai. Sari (2016) menyatakan LKPD merupakan alat bantu untuk membangun pengetahuan peserta didik dan sangat diperlukan dalam proses pembelajaran. LKPD yang baik menurut Permendikbud Nomor 8 Tahun 2016 adalah LKPD yang dapat mengarahkan peserta didik pada pembelajaran aktif. LKPD yang banyak digunakan sekarang adalah LKPD yang sudah jadi atau LKPD dari penerbit dan belum sesuai dengan tuntutan Kurikulum 2013. LKPD tersebut hanya digunakan untuk mengevaluasi hasil belajar peserta didik yang diberikan di akhir pembelajaran atau digunakan sebagai pekerjaan rumah. Soal-soal yang disajikan dalam LKPD kurang variatif di mana peserta didik diminta mengisi titik titik atau menjawab soal pilihan ganda sehingga tidak mampu memicu peserta didik untuk aktif dan berpikir tingkat tinggi. Sebenarnya LKPD bukan hanya sekedar pelengkap penjelasan suatu konsep atau alat bantu pendidik dalam pembelajaran tetapi berfungsi sebagai pemicu untuk menemukan konsep itu sendiri serta mengarahakan peserta didik untuk belajar mandiri, meningkatkan kemampuan berpikir kritis dan melatih kemampuan peserta didik dalam pemecahan masalah dan meningkatkan kemampuan peserta didik belajar secara kolaboratif dalam sebuah tim dan dengan orang lain. LKPD merupakan bahan ajar tertulis yang di dalamnya berisi aktivitas individu atau kelompok di mana peserta didik bekerja sambil mempelajari suatu masalah yang memungkinkan peserta didik bertanggung jawab atas pengetahuan dengan proses tahapan yang diberikan terkait aktivitas belajar peserta didik atau LKPD merupakan alat penunjang dalam meningkatkan kualitas pembelajaran di kelas. Kondisi ini menuntut para pendidik harus kreatif dan inovatif dalam membuat perangkat pembelajaran seperti LKPD yang sesuai dengan tuntutan kurikulum
2013 dan perkembangan zaman. LKPD menurut Depdiknas (2008) adalah lembaranlembaran tugas yang berisi petunjuk dan langkah-langkah untuk menyelesaikan suatu permasalahan yang harus dikerjakan peserta didik.

Bahan ajar cetak berupa lembar-lembar kertas yang berisi materi, ringkasan, dan petunjukpetunjuk pelaksanaan tugas pembelajaran yang harus dikerjakan oleh peserta didik, yang mengacu pada kompetensi dasar yang harus dicapai disebut LKPD (Prastowo, 2011). Hal ini berarti bahwa LKPD dapat menunjang peningkatan aktivitas peserta didik dalam belajar dan membantu guru untuk mengarahkan peserta didik menemukan konsep melalui aktivitas sendiri, mengembangkan keterampilan proses, dan meminimalkan peran pendidik dalam pembelajaran. Dalam proses pembelajaran manfaat LKPD sangat sangat besar karena 1) LKPD dapat meningkatkan aktivitas peserta didik dalam belajar; 2) penggunaannya dalam pembelajaran dapat membantu guru mengaktifkan peserta didik dalam belajar dan membantu guru mengarahkan peserta didik menemukan konsep melalui aktivitas sendiri; 3) LKPD dapat melatih peserta didik mengembangkan keterampilan proses dan mengoptimalkan hasil belajar serta sebagai pedoman dalam pembelajaran; 4) LKPD dapat mengembangkan kreativitas berpikir peserta didik dalam memecahkan berbagai permasalahan yang berhubungan dengan kehidupan sehari-hari; 5) LKPD dapat membimbing dan mengarahkan serta memberdayakan peserta didik untuk belajar mandiri, meningkatkan kemampuan berpikir kritis, dan meningkatkan kemampuan untuk belajar secara kolaboratif dalam sebuah tim dan dengan orang lain.

Kaymakci (2012) menyatakan bahwa "Worksheet is one of the most important 
materials for achieving the goals of educational activities". Pernyataan ini menunjukkan bahwa LKPD merupakan satu bahan ajar yang paling penting untuk mencapai tujuan-tujuan dari aktivitas-aktivitas pendidikan. LKPD mempunyai peran penting dalam pembelajaran kimia karena LKPD dapat menjadikan peserta didik lebih aktif dalam belajar kimia, menjadikan peserta didik lebih mandiri, dan memberikan kesempatan kepada peserta didik untuk mengembangkan kemampuan berpikir kritis peserta didik, sehingga pembelajaran berpusat pada peserta didik. Di sisi lain, $P B L$ adalah salah satu model pembelajaran aktif dan efektif untuk digunakan dalam pembelajaran serta dapat membangkitkan keterampilan berpikir kritis dan kemandirian belajar peserta didik.

$P B L$ ini dipilih dalam pengembangan LKPD didasari oleh beberapa alasan, yakni 1) $P B L$ merupakan model pembelajaran yang membantu pendidik dalam mengaitkan materi dengan situasi nyata; 2) $P B L$ dapat memfasilitasi keberhasilan peserta didik dalam memecahkan masalah, komunikasi, kerja kelompok dan keterampilan interpersonal dengan baik (Rusman, 2012) PBL dapat merangsang peserta didik untuk belajar karena menyajikan masalah secara nyata; 4) $P B L$ dapat mengembangkan dan mempertahankan keterampilan belajar mandiri sehingga pembelajaran lebih bermakna, ditandai dengan mengolah materi pelajaran secara kritis (Malan \& Ndlovu, 2014); 5) peserta didik dalam tim akan bekerja untuk memecahkan masalah dunia nyata (real world) (Majid, 2014), sehingga meningkatkan interaksi antar sesama peserta didik serta menambah keterampilan peserta didik dalam menyelesaikan permasalahan kehidupan nyata.

Karakteristik dari model $P B L$ adalah pembelajaran yang didominasi oleh peserta didik. Model PBL adalah model yang disarankan oleh Kementerian Pendidikan Nasional untuk diaplikasikan dalam proses pembelajaran Kurikulum 2013 yang dapat mengoptimalkan aktivitas saintifik siswa. $P B L$ adalah model pembelajaran yang dapat merangsang peserta didik untuk belajar melalui berbagai permasalahan nyata dalam kehidupan sehari-hari yang dikaitkan dengan pengetahuan yang dia miliki atau yang akan dipelajarinya serta berfungsi sebagai wadah yang digunakan untuk mengembangkan cara berpikir kritis dan keterampilan berpikir yang lebih tinggi bagi peserta didik (Gunantara dkk., 2014).

Dalam mempelajari suatu materi peserta didik harus menggali pengetahuannya dan pendidik harus memberi kesempatan yang luas terhadap peserta didik sehingga peserta didik dapat mengembangkan dan menggali pengetahuannya namun tetap dalam bimbingan pendidik.

Solusi untuk menjawab problematika pendidikan yang berhubungan dengan pembelajaran di atas, maka perlu dikembangkan LKPD pada pembelajaran kimia menggunakan $P B L$. Hal ini karena $P B L$ tersebut merupakan salah satu model pembelajaran yang disaran dalam Kurikulum 2013 dan juga merupakan model yang dapat menyelesaikan problematika pendidikan di atas. LKPD yang dikembangkan di dalamnya terdapat langkahlangkah pembelajaran PBL mencakup permasalahan yang dapat membangkitkan keterampilan berpikir kritis dan kemandirian belajar peserta didik. Pengembangan LKPD berbasis $P B L$ pada materi ikatan kimia kelas $X$ diharapkan dapat membantu pendidik dalam mencapai tujuan pembelajaran, meningkatkan aktivitas belajar peserta didik, meminimalkan peranan pendidik tetapi lebih mengaktifkan peranan peserta didik, mengembangkan kreativitas berpikir peserta 
didik dalam memecahkan masalah, memberdayakan peserta didik untuk belajar mandiri, meningkatkan kemampuan berpikir kritis, dan meningkatkan kemampuan untuk belajar secara kolaboratif dalam sebuah tim dan dengan orang lain sehingga dengan hal tersebut dapat memperkaya pengetahuan peserta didik.

Model pembelajaran Problem Based Learning adalah model pembelajaran yang menuntut adanya aktivitas peserta didik secara penuh dalam rangka menyelesaikan setiap permasalahan yang dihadapi peserta didik secara mandiri dengan cara mengonstruksi pengetahuan dan pemahaman yang dimiliki (Wardoyo, 2013).

Model pembelajaran Problem Based Learning sebelumnya telah dicantumkan pendidik dalam RPP. Model ini dipilih karena dapat memberikan pengalaman belajar yang lebih bermakna dan lebih luas mulai dari memahami konsep sampai dengan bagaimana mengaplikasikan konsep yang dipelajari (Mudlofir dan Rusydiyah, 2017).

Pembelajaran PBL menuntut peserta didik untuk menyusun pengetahuan mereka sendiri, membangun pemahamannya melalui tahaptahap ilmiah dan juga menuntut peserta didik untuk memiliki keterampilan berpikir ke tingkat yang lebih tinggi dan sangat fleksibel untuk dilaksanakan karena dapat digunakan untuk desain pembelajaran individu (individual learning) maupun pembelajaran secara kelompok (cooperative learning).

Adapun tahap-tahap pembelajaran Problem Based Learning menurut Trianto (2015) yaitu orientasi peserta didik pada masalah, organisasi peserta didik untuk belajar, membimbing penyelidikan kelompok maupun individual, mengembangkan dan menyajikan hasil karya, menganalisis dan mengevaluasi proses pemecahan masalah. Pembelajaran Problem Based Learning (PBL) memiliki beberapa kelebihan. Kelebihan Problem Based Learning $(\mathrm{PBL})$ ialah sebagai berikut:

1) Pembelajaran lebih bermakna karena peserta didik belajar memecahkan suatu masalah sendiri dan menerapkan pengetahuannya dalam memecahkan masalah tersebut sehingga mempermudah peserta didik dalam menguasai konsep yang dipelajari.

2) Selama proses pembelajaran berlangsung peserta didik dapat mengintegrasikan pengetahuan dan keterampilan yang yang dia miliki secara simultan serta mengaplikasikannya dalam konteks yang relevan, artinya apa yang dia lakukan sesuai dengan keadaan nyata sehingga masalahmasalah atau teori akan mereka temukan secara bersamaan atau sekaligus.

3) Masalah-masalah yang ditampilkan di dalam pembelajaran berhubungan dengan masalah dunia nyata sehingga dapat meningkatkan motivasi dan ketertarikan peserta didik terhadap materi yang dipelajarinya.

4) Mengembangkan kemampuan berpikir kritis, menumbuh inisiatif dan kemandirian belajar peserta didik serta mengembangkan hubungan interpersonal dalam belajar kelompok.

Banyak penelitian yang telah dilakukan terkait pengembangan bahan ajar, seperti penelitian yang dilakukan oleh Karsli dan Sahin (2009) yang menunjukkan bahwa LKPD berbasis keterampilan proses sains mampu meningkatkan aktivitas belajar peserta didik. Hasil penelitian Vivi Dwi Kurniawati dkk. (2014) dengan judul "Pengembangan Perangkat Pembelajaran Berbasis Problem Based 
Learning $(P B L)$ pada Mata Pelajaran Biologi Materi Klasifikasi Tumbuhan untuk Meningkatkan Kompetensi Siswa Kelas X SMA Taman Harapan Malang" telah menghasilkan perangkat pembelajaran dengan katagori valid, kepraktisan dengan katagori baik serta keefektifan dengan katagori tinggi. Penelitian Eka Sari dkk. (2016) dengan judul "Pengembangan Lembar Kegiatan Peserta Didik (LKPD) Berbasis Karakter pada Mata Pelajaran Kimia SMA" menghasilkan sebuah produk LKPD berbasis nilai karakter yang layak digunakan dalam pembelajaran. Kemudian dalam penelitian Chong et al. (2013) dikatakan bahwa LKPD mampu memberikan pemahaman konsep peserta didik pada materi ikatan logam. Selaras dengan penelitian Fitriani dkk. (2016) dengan judul "Pengembangan Lembaran Kegiatan Peserta Didik (LKPD) Berbasis Masalah untuk Meningkatkan Pemahaman Konsep dan Aktivitas Belajar Peserta Didik pada Materi Larutan Penyangga" serta penelitian Sri Astuti (2018) dengan judul "Pengembangan LKPD Berbasis PBL (Problem Based Learning) untuk Meningkatkan Keterampilan Berpikir Kritis Peserta Didik pada Materi Kesetimbangan Kimia".

Berdasarkan uraian latar belakang di atas penelitian ini bertujuan untuk menghasilkan LKPD berbasis Problem Based Learning (PBL) untuk siswa Kelas X MIPA SMA/MA yang valid dan praktis.

\section{METODE PENELITIAN}

Penelitian pengembangan ini dilakukan di Program Pascasarjana pendidikan Kimia FKIP Universitas Riau. Metode yang digunakan dalam penelitian ini adalah Research and Development (R\&D). Research and Development merupakan jenis penelitian yang bersifat analisis deskriptif dengan prosedur kerja bertahap untuk menghasilkan atau menguji sebuah produk pendidikan. Penelitian dan pengembangan menurut Nana Syaodih Sukmadinata (2006) adalah suatu proses atau langkah-langkah yang harus dipertanggung jawabkan yang digunakan untuk mengembangkan suatu produk atau menyempurnakan produk yang sudah ada. Langkah-langkah yang digunakan dalam penelitian ini merujuk pada model Borg and Gall (Tim Puslitjaknov, 2008). Peneliti dalam penelitian ini mencoba mengembangkan produk yaitu LKPD Kimia dengan menggunakan $P B L$ pada materi ikatan kimia menggunakan model pengembangan Borg and Gall. Borg and Gall dalam Endang Mulyatiningsih (2014) mengemukan langkahlangkah dalam penelitian pengembangan ada 10 tahap yaitu 1) penelitian pendahuluan dan pengumpulan informasi (Research and Information Collection); 2) perencanaan (Planning); 3) pengembangan produk awal (Develop Preliminary Form of Product); 4) uji coba lapangan awal (Preliminary Field Testing); 5) revisi produk awal (Main Product Revision); 6) uji coba lapangan utama (Main Field Testing); 7) revisi produk hasil uji coba lapangan utama (Operational Product Revision); 8) uji coba pelaksanaan lapangan/pemakai (Operational Field Testing); 9) revisi produk akhir (Final Product Revision); 10) diseminasi dan implementasi (Dissemination and Implementation).

Data yang dihasilkan dari pengembangan ini berupa data kualitatif dan data kuantitatif. Jenis data yang dikumpulkan dalam penelitian ini adalah data validasi LKPD dan data respon pendidik dan peserta didik sebagai pengguna LKPD berbasis Problem Based Learning (PBL). Secara teknis data validasi LKPD Ikatan Kimia diperoleh dari tiga orang validator, tiga orang pendidik serta 30 orang peserta didik dari tiga sekolah yang berbeda yaitu 10 peserta didik SMAN 1 Bangkinang Kota, 10 peserta didik 
SMAN 2 Bangkinang, dan 10 orang peserta didik SMAN 1 Salo sebagai pengguna.

Instrumen yang digunakan dalam penelitian ini adalah lembar validasi LKPD untuk ahli materi serta lembar angket respon pendidik dan peserta didik terhadap LKPD yang dikembangkan. Saran dan masukan dari validator ahli dan pendidik mengenai apakah LKPD Ikatan Kimia layak digunakan atau tidak digunakan sebagai bahan ajar dalam kegiatan pembelajaran digunakan untuk memperbaiki LKPD yang dirancang atau yang dikembangkan oleh peneliti. Penilaian terhadap kevalidan LKPD Ikatan Kimia terdiri dari 4 poin penilaian yakni dengan poin 4 (valid), 3 (cukup valid), 2 (kurang valid), 1 (tidak valid). Selanjutnya tanggapan para validator dianalisis secara deskriptif dengan merataratakan skor untuk tiap komponen dan aspek dari semua validator. Sedangkan penilaian respon pendidik dan peserta didik sebagai pengguna LKPD Ikatan Kimia terdiri dari 4 poin penilaian yakni dengan poin 4 (sangat setuju), 3 (setuju), 2 (tidak setuju), 1 (sangat tidak setuju). Teknik analisis data yang digunakan adalah analisis deskriptif kualitatif yang bertujuan untuk mendeskripsikan hasil validitas yang diberikan validator, yaitu dengan cara menghitung persentase nilai validasi.

$$
\text { Persentase }=\frac{\text { Skor yang diperoleh }}{\text { Skor maksimum }} \times 100 \%
$$

Kriteria dalam pengambilan keputusan untuk validasi LKPD dapat dilihat pada Tabel 1 di bawah ini. Tingkat kelayakan produk hasil penelitian pengembangan LKPD dapat dilihat dari besarnya skor persentase hasil analisis data.
Tabel 1. Kriteria Kelayakan Analisis Persentase (Riduwan, 2016)

\begin{tabular}{cl}
\hline \multicolumn{1}{c}{ Parsentase } & \multicolumn{1}{c}{ Keterangan } \\
\hline $80,00-100$ & Baik/Valid/ Layak \\
$60,00-79,99$ & Cukup Baik/ CukupValid/ \\
& Cukup Layak \\
$50,00-59,00$ & $\begin{array}{l}\text { Kurang Baik/ Kurang Valid/ } \\
\text { Kurang Layak }\end{array}$ \\
$0,00-49,99$ & Tidak Baik (diganti) \\
\hline
\end{tabular}

Sedangkan kriteria penilaian angket respon pendidik dan peserta didik terhadap LKPD yang dikembangkan adalah:

Tabel 2. Kriteria Penilaian Respon Pendidik dan Peserta Didik

\begin{tabular}{ll}
\hline \multicolumn{1}{c}{ Parsentase } & \multicolumn{1}{c}{ Keterangan } \\
\hline $0,00-20,00$ & Sangat tidak setuju \\
$21,00-40,00$ & Tidak setuju \\
$41,00-60,00$ & Netral \\
$61,00-80,00$ & Setuju \\
$81,00-100$ & Sangat setuju \\
\hline (Riduwan, 2016, dan diadaptasi oleh peneliti).
\end{tabular}

\section{HASIL DAN PEMBAHASAN}

Hasil dari penelitian dan pengembangan LKPD berbasis $P B L$ pada materi ikatan kimia kelas $X$ adalah LKPD yang valid dan praktis. Berikut diuraikan prosedur pengembangan LKPD beradasarkan model Borg and Gall:

a) Pendahuluan dan pengumpulan informasi (Research and Information Collection). Pengumpulan informasi awal dilakukan dengan studi lapangan dan studi literatur.

1) Studi lapangan dilakukan untuk mengidentifikasi masalah dan melakukan pengumpulan data serta menentukan salah satu pokok bahasan yang sulit. Analisis yang dilakukan dalam studi lapangan adalah analisis kebutuhan, analisis kondisi belajar, dan analisis kurikulum. 
- Analisis kebutuhan berfungsi untuk melihat kebutuhan pendidik dan peserta didik dalam pembelajaran.

- Analisis kondisi belajar berfungsi untuk melihat bagaimana kondisi pembelajaran yang berlangsung di kelas sebelum dilakukan penelitian. Yang dilakukan sebelum melakukan analisis kondisi belajar adalah observasi dan wawancara dengan guru kimia kelas $X$ IPA tentang kegiatan pembelajaran di kelas. Hasil inilah yang dijadikan sebagai acuan oleh peneliti dalam melakukan analisis kondisi belajar peserta didik.

- Analisis kurikulum digunakan untuk melihat kurikulum yang digunakan sekolah sehingga pengembangan produk dapat disesuaikan dengan kurikulum yang diberlakukan.

2) Studi literatur digunakan untuk menentukan kajian telaah literatur yaitu untuk mendapatkan analisis KI dan KD materi pembelajaran serta mengkaji penelitian yang relevan dengan penelitian yang akan dilakukan.

b) Perencanaan (Planning). Tahap perencanaan bertujuan untuk mempersiapkan bahan dan membuat rancangan produk LKPD yang dimulai dari pemetaan materi, menentukan judul, merumuskan indikator pembelajaran, merumusan tujuan pembelajaran, desain kerangka LKPD, menentukan isi bagianbagian LKPD yang akan dikembangkan serta pengumpulan bahan dari berbagai sumber.

c) Pengembangan produk awal (Develop Preliminary of Product). Bagian-bagian yang telah direncanakan disusun dan didesain menjadi sebuah draft produk awal (draft 1) kemudian dikonsultasikan dengan dosen pembimbing. Pada tahap ini juga disusun instrumen evaluasi untuk menilai kualitas produk LKPD.

d) Uji coba lapangan awal (Preliminery Field Testing). Setelah produk draft 1 diperbaiki kemudian diajukan kepada tiga orang dosen untuk divalidasi. Selanjutnya hasil evaluasi, koreksi dan saran dari validator dijadikan acuan untuk memperbaiki draft 1 sebelum diuji coba lapangan awal. Setelah draft 1 diperbaiki baik dari segi konten materi maupun desain LKPD sesuai saran maka dihasilkan draft 2 yang telah layak dan valid untuk diuji cobakan. Kemudian dilakukan uji coba awal.

e) Revisi produk awal (Main Product Revision). Setelah produk awal divalidasi oleh tiga orang validator ahli, maka LKPD yang akan diperbaiki/ direvisi sesuai saran dan masukan dari validator. Revisi dilakukan sebanyak dua kali.

f) Uji lapangan utama (Main Field Testing). Uji coba lapangan utama disebut juga dengan uji coba terbatas di mana dalam tahap ini LKPD yang telah divalidasi oleh validator akan dinilai kemenarikan dan kemudahannya oleh pendidik dan peserta didik sebagai pengguna melalui angket respon pendidik dan peserta didik. Angket respon pendidik diberikan kepada tiga orang guru, sedangkan angket respon peserta didik diberikan kepada peserta didik yang berasal dari tiga sekolah yang berbeda yaitu 10 orang siswa SMAN 1 Bangkinang Kota, 10 siswa SMAN 2 Bangkinang Kota dan 10 orang siswa SMAN 1 Salo. Berdasarkan hasil uji lapangan utama yang dilakukan diperoleh nilai ratarata dari pendidik dan peserta didik dengan 
katagori sangat setuju dan layak digunakan.

Namun karena keterbatasan waktu penelitian dilakukan hanya sampai tahap uji lapangan utama (Main Field Testing). Berikut ini data hasil validasi LKPD dan data hasil respon pendidik serta data hasil respon peserta didik sebagai pengguna.

\section{a. Aspek Isi}

Tujuh komponen penilaian yang terdapat dalam aspek isi adalah sebagai berikut:

1. Capaian pembelajaran dan indikator

2. Kedalaman materi sesuai dengan kemampuan peserta didik

3. Konsep-konsep berhubungan dengan kehidupan sehari-hari

4. Substansi materi ikatan kimia

5. Bersifat mengarahkan peserta didik untuk membangun konsep

6. Menggiring peserta didik untuk diskusi dan komunikasi

7. Menggiring peserta didik memecahkan permasalahan.

Skor rata-rata penilaian aspek isi adalah $98,3 \%$. Berdasarkan hasil penilaian aspek isi dapat dikatakan bahwa LKPD yang dikembangkan memiliki aspek isi yang valid.

\section{b. Aspek Penyajian}

Empat komponen penilaian pada aspek penyajian, antara lain:

1. Kelengkapan format

2. Menyediakan ruang luas bagi peserta didik untuk menulis maupun menggambarkan hal-hal yang ingin disampaikan.

3. Keruntunan sistematika

4. Meningkatkan aktivitas belajar peserta didik
Skor rata-rata penilaian aspek penyajian adalah 98,3\%. Berdasarkan hasil penilaian aspek penyajian dapat dikatakan bahwa LKPD yang dikembangkan memiliki aspek penyajian yang valid.

\section{c. Aspek Bahasa}

Lima komponen penilaian aspek bahasa antara lain:

1. Informasi mudah dipahami

2. Kaidah bahasa Indonesia yang baku

3. Struktur kalimat jelas

4. Bahasa sesuai dengan tingkat kemampuan peserta didik

5. Konsisten

Skor rata-rata penilaian aspek bahasa adalah 93,3\%. Berdasarkan hasil penilaian aspek bahasa dapat dikatakan bahwa LKPD yang dikembangkan memiliki aspek bahasa yang valid.

\section{d. Aspek Kegrafisan}

Empat komponen penilaian kegrafisan ialah:

1. Jenis dan ukuran huruf baik dan menarik

2. Tata letak (layout) menarik

3. Ilustrasi/ gambar/ foto berhubungan dengan konsep

4. Desain tampilan menarik

Skor rata-rata penilaian aspek kegrafisan adalah 95,8\%. Berdasarkan hasil penilaian aspek kegrafisan dapat dikatakan bahwa LKPD yang dikembangkan memiliki aspek kegrafisan yang valid. 


\section{e. Aspek Karakteristik PBL}

Enam komponen penilaian aspek karakteristik $P B L$ adalah sebagai berikut:

1. Pembelajaran dimulai dengan satu masalah konstektual yang berhubungan dengan dunia nyata yang dapat mendorong rasa ingin tahu peserta didik sehingga muncul berbagai macam pertanyaan disekitar masalah

2. Masalah yang disajikan medorong peserta didik untuk berpikir kritis dan memotivasi peserta didik agar dapat terlibat langsung dalam memecahkan masalah pembelajaran

3. Di dalam LKPD terdapat langkah-langkah kegiatan pembelajaran Problem Based Learning
4. Memberikan kesempatan kepada peserta didik agar saling bekerja sama untuk memecahkan suatu permasalahan

5. Ada penekanan hal-hal penting, peserta didik diberi kesempatan untuk menyimpulkan materi yang dipelajari

6. Terdapat penilaian (evaluasi) berupa latihan soal untuk setiap kegiatan yang dilakukan peserta didik

Skor rata-rata penilaian aspek karakteristik $P B L$ adalah 100 \%. Berdasarkan hasil penilaian aspek karakteristik $P B L$ dapat dikatakan bahwa LKPD yang dikembangkan memiliki aspek karakteristik $P B L$ yang valid. Rekapitulasi kelima aspek penilaian LKPD oleh tiga validator dapat dilihat pada Tabel 3 berikut.

Tabel 3. Rekapitulasi Skor Rata-rata Penilaian Kelima Aspek Kelayakan LKPD

\begin{tabular}{|c|l|c|c|c|c|c|}
\hline No & \multicolumn{1}{|c|}{ Aspek yang dinilai } & $\begin{array}{c}\text { Skor } \\
\text { Rata-rata } \\
\text { Validator 1 }\end{array}$ & $\begin{array}{c}\text { Skor } \\
\text { Rata-rata } \\
\text { Validator 2 }\end{array}$ & $\begin{array}{c}\text { Skor } \\
\text { Rata-rata } \\
\text { Validator 3 }\end{array}$ & $\begin{array}{c}\text { Jumlah } \\
\text { Skor } \\
\text { Validasi }\end{array}$ & $\begin{array}{c}\text { Nilai kelayakan } \\
\text { (\%) }\end{array}$ \\
\hline 1 & Aspek isi & 4 & 3,8 & 4 & 11,8 & $98,3 \%$ \\
\hline 2 & Aspek penyajian & 4 & 4 & 3,8 & 11,8 & $98,3 \%$ \\
\hline 3 & Aspek bahasa & 3,4 & 3,8 & 4 & 11,2 & $93,3 \%$ \\
\hline 4 & Aspek kegrafisan & 4 & 4 & 3,5 & 11,5 & $95,8 \%$ \\
\hline 5 & Aspek Karakteristik PBL & 4 & 4 & 4 & 12 & $100 \%$ \\
\hline Jumlah Skor & 19,4 & 15,6 & 19,3 & 58,3 & $485,7 \%$ \\
\hline \multicolumn{2}{|l|}{ Rata Rata Skor } & 3,9 & 3,1 & 3,9 & 11,66 & $97,1 \%$ \\
\hline
\end{tabular}

Hasil penilaian kelayakan LKPD oleh tiga orang validator dilihat segi aspek isi, aspek penyajian, aspek bahasa, aspek kegrafisan dan aspek karakteristik $P B L$ yang digambarkan dalam bentuk diagram batang dalam Gambar 1 .

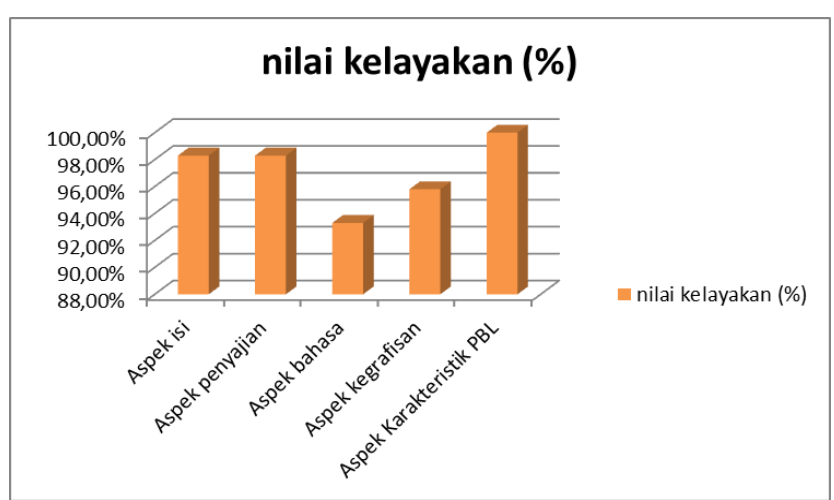

Gambar 1. Hasil Validasi LKPD 
Berdasarkan hasil validasi LKPD berbasis PBL pada materi ikatan kimia oleh tiga orang validator diperoleh nilai rata-rata sebesar 11,66 dengan persentase 97,1\% maka, LKPD Ikatan Kimia dapat diinterpretasikan dalam kategori valid dan layak digunakan dalam kegiatan pembelajaran. Hal ini juga sepadan dengan hasil penelitian yang dilakukan oleh Mayang Larasati (2018) dengan judul "Pengembangan Modul Berbasis Problem Based Learning pada Pateri Polimer" dengan hasil sangat layak dan persentase sebesar 89\%. Untuk memperkuat hasil penelitian mengenai kevalidan LKPD berbasis PBL pada materi ikatan kimia, maka pengambilan respon tanggapan pendidik dan peserta didik sebagai pengguna di lapangan juga dilakukan. Lembar angket respon pendidik dan peserta didik terhadap kemenarikan dan kemudahan LKPD yang berbasis Problem Based Learning $(P B L)$ diberikan kepada tiga orang guru dan 30 orang peserta didik yang berasal dari tiga SMA yang berbeda yaitu 10 siswa SMAN 1 Bangkinang Kota, 10 orang siswa SMAN 2 Bangkinang Kota, dan 10 orang siswa SMAN 1 Salo.

\section{Tabel 4. Data Hasil Respon Pendidik}

\begin{tabular}{|c|c|c|c|c|c|c|}
\hline \multirow[t]{2}{*}{ No } & \multirow[t]{2}{*}{ Pernyataan } & \multicolumn{3}{|c|}{ Jawaban pendidik } & \multirow[t]{2}{*}{ Jumlah } & \multirow[t]{2}{*}{$\%$} \\
\hline & & 1 & 2 & 3 & & \\
\hline \multicolumn{7}{|c|}{ Tanggapan pendidik terhadap kelayakan isi LKPD } \\
\hline 1 & $\begin{array}{l}\text { Materi yang disajikan dalam LKPD sesuai dengan } \\
\text { tingkat kemampuan peserta didik }\end{array}$ & 4 & 4 & 4 & 12 & $100 \%$ \\
\hline 2 & $\begin{array}{l}\text { LKPD mendorong peserta didik untuk berdiskusi atau } \\
\text { bekerja sama dengan orang lain dalam satu kelompok }\end{array}$ & 4 & 4 & 4 & 12 & $100 \%$ \\
\hline 3 & $\begin{array}{l}\text { Petunjuk kegiatan dalam LKPD jelas sehingga } \\
\text { mempermudah peserta peserta didik melakukan semua } \\
\text { semua kegiatan yang ada dalam LKPD }\end{array}$ & 4 & 3 & 4 & 11 & $91,7 \%$ \\
\hline 4 & $\begin{array}{l}\text { LKPD membantu peserta didik untuk menemukan } \\
\text { konsep dengan caranya sendiri }\end{array}$ & 4 & 4 & 3 & 11 & $91,7 \%$ \\
\hline 5 & $\begin{array}{l}\text { Konsep yang disajikan dalam LKPD tidak menimbulkan } \\
\text { banyak tafsiran dan sesuai dengan konsep kimia }\end{array}$ & 3 & 3 & 4 & 10 & $83,3 \%$ \\
\hline 6 & $\begin{array}{l}\text { LKPD memfasilitasi siswa untuk membangun } \\
\text { pemahaman berdasarkan pengetahuan yang telah } \\
\text { dimilki sebelumnya }\end{array}$ & 4 & 4 & 4 & 12 & $100 \%$ \\
\hline 7 & $\begin{array}{l}\text { LKPD memfasilitasi siswa untuk menggali informasi } \\
\text { yang dibutuhkan untuk menyelesaikan masalah }\end{array}$ & 4 & 4 & 4 & 12 & $100 \%$ \\
\hline 8 & LKPD menuntut peserta didik untuk berpikir kritis & 4 & 4 & 4 & 12 & $100 \%$ \\
\hline 9 & $\begin{array}{l}\text { LKPD dapat digunakan sebagai bahan belajar meskipun } \\
\text { tidak dalam bimbingan guru }\end{array}$ & 4 & 4 & 4 & 12 & $100 \%$ \\
\hline 10 & $\begin{array}{l}\text { Gambar dan iliustrasi dalam LKPD yang disajikan } \\
\text { berdasarkan sehari hari dan efisien untuk untuk } \\
\text { meningkatkan pemahaman siswa }\end{array}$ & 4 & 3 & 4 & 11 & $91,7 \%$ \\
\hline 11 & $\begin{array}{l}\text { Tahapan-tahapan Problem Based Learning }(P B L) \text { yang } \\
\text { disajikan dalam LKPD memudahkan peserta didik } \\
\text { untuk membangun pengetahuan mengenai materi } \\
\text { lkatan Kimia. }\end{array}$ & 4 & 4 & 4 & 12 & $100 \%$ \\
\hline
\end{tabular}




\begin{tabular}{|c|c|c|c|c|c|c|}
\hline \multirow{2}{*}{ No } & \multirow[t]{2}{*}{ Pernyataan } & \multicolumn{3}{|c|}{ Jawaban pendidik } & \multirow[t]{2}{*}{ Jumlah } & \multirow[t]{2}{*}{$\%$} \\
\hline & & 1 & 2 & 3 & & \\
\hline \multicolumn{7}{|c|}{ Tanggapan pendidik terhadap kesesuaian dengan silabus } \\
\hline 12 & $\begin{array}{l}\text { Materi yang disajikan dalam LKPD mencakup semua } \\
\text { materi yang terkandung yang terkandung dalam } \\
\text { kompetensi Dasar (KD) }\end{array}$ & 4 & 4 & 4 & 12 & $100 \%$ \\
\hline 13 & $\begin{array}{l}\text { Materi yang disajikan dalam LKPD membantu peserta } \\
\text { didik untuk mencapai tujuan pembelajaran yang telah } \\
\text { diisyaratkan dalam indikator pencapaian Kompetensi } \\
\text { Dasar }\end{array}$ & 4 & 4 & 4 & 12 & $100 \%$ \\
\hline \multicolumn{7}{|c|}{ Tanggapan pendidik terhadap tata bahasa yang digunakan dalam LKPD } \\
\hline 14 & $\begin{array}{l}\text { LKPD menggunakan bahasa yang yang sopan dan } \\
\text { sesuai }\end{array}$ & 4 & 4 & 4 & 12 & $100 \%$ \\
\hline 15 & Bahasa yang digunakan dalam LKPD komunikatif & 4 & 3 & 4 & 11 & $91,7 \%$ \\
\hline 16 & Struktur kalimat yang digunakan dalam LKPD jelas & 3 & 4 & 4 & 11 & $91,7 \%$ \\
\hline 17 & $\begin{array}{l}\text { LKPD menggunakan kalimat yang tidak menimbulkan } \\
\text { makna ganda }\end{array}$ & 4 & 3 & 4 & 11 & $91,7 \%$ \\
\hline 18 & $\begin{array}{l}\text { Kalimat yang digunakan dalam LKPD sederhana dan } \\
\text { mudah dipahami }\end{array}$ & 4 & 4 & 3 & 11 & $91,7 \%$ \\
\hline \multicolumn{2}{|c|}{ Jumlah } & 70 & 67 & 70 & 207 & $1725,2 \%$ \\
\hline \multicolumn{2}{|c|}{ Rata-rata } & 3,8 & 3,7 & 3,8 & 11,3 & $95,8 \%$ \\
\hline
\end{tabular}

Hasil rata-rata analisis angket respon pendidik dari 3 orang pendidik terhadap kemenarikan dan kemudahan LKPD berbasis Problem Based Learning yang dikembangkan adalah 11,5 dengan persentase sebesar $95,8 \%$ berada dalam kategori sangat setuju digunakan dalam kegiatan pembelajaran. Sedangakan angket respon peserta didik terhadap kemenarikan dan kemudahan LKPD berbasis Problem Based Learning yang dikembangkan adalah sebesar 96,3\%.

\section{KESIMPULAN}

Berdasarkan proses pengembangan yang telah dilakukan diperoleh hasil Lembar Kerja Peserta Didik (LKPD) berbasis Problem Based Learning pada materi Ikatan Kimia yang valid dan layak digunakan dan telah melalui proses validasi, uji coba terbatas serta telah dinyatakan memenuhi aspek isi, aspek penyajian, aspek bahasa, aspek kegrafisan, dan aspek karakteristik $P B L$. 


\section{DAFTAR PUSTAKA}

Alfatie, W. G. (2009). Identifikasi Kesulitan Siswa Kelas XII IPA-2 MAN 1 Malang Dalam Memahami Materi Kelarutan Dan Hasil Kelarutan (KSP) Serta Pemahaman Materi tersebut dalam Kehidupan seharihari. [Online] http:// karyailmiahum.ac.id/indek.php/kimia/ar ticle/view/2776 diakses pada tanggal 5 Januari 2018.

Astuti, S. (2018). Pengembangan LKPd berbasis PBL (Problem Based Learning) untuk meningkatkan keterampilan berpikir kritis peserta didikl pada materi kesetimbangan Kimia. Chemistry Education Review (CER), 1(2), 90-114.

Cardellini, L. (2012). Chemistry: Why the Subject is Difficult. México: Universidad Nacional Autónoma de México, ISSNE 1870-8404.

Chong, V. D., Salleh, S. M. \& Aicheong, I. P. (2013). Using an Activity Worksheet to Remediate Students' Alternative Conceptions of Metallic Bonding. American International Journal of Contemporary Research, 3(11).

Chun Wu \& Foos, Jordan. (2010). Mount Marty College, USA Making Chemistry Fun to Learn. Literacy Information and Computer Education Journal (LICEJ), 1.

Depdiknas. (2008). Pengembangan Bahan Ajar. Jakarta: Direktorat Pembinaan Sekolah Menengah Atas Direktorat Jenderal Manajemen Pendidikan Dasar dan Menengah Departemen Pendidikan Nasional.

Fitriani, dkk (2016) Pengembangan lembaran kegiata $\mathrm{n}$ peserta didik (LKPD) berbasis masalah untuk meningkatkan pemahaman konsep dan aktivitas belajar peserta didik pada materi larutan penyangga. Jurnal Pendidikan Sains Indonesia, 4(2), 24-35.

Gunantara, S. \& Riastini, N. (2014). Penerapan Model Pembelajaran Problem Based Larning untuk Meningkatkan Kemampuan Pemecahan Masalah Matematika Siswa Kelas V. Jurnal Mimbar PGSD Universitas Pendidikan Ganesha, 2(1).

Kaymakci, S. (2012). A Review of Studies on Worksheets in Turkey.Turkey: Karadeniz Technical University. [Online]: http://files.eric.ed.gov/fulltext/ED53069 9.pdf diakses pada tanggal 2 April 2018.

Karsli, F. \& Sahin, C. (2009). Developing Worksheet Based on Science Process Skills: Factors Affecting Solubility. AsiaPacific Forum on Science Learning and Teaching, 10(15).

Kawiyah, S. (2015). Pengembangan Perangkat Pembelajaran Matematika Berbasis Saintifik untuk Meningkatkan Kemampuan Pemecahan Masalah dan Prestasi Belajar Siswa. Jurnal Pendidikan Matematika, 10(2), 201-210.

Kemendikbud. (2013). Materi Pelatihan Guru Implementasi Kurikulum 2013 Tentang Standar Proses Pendidikan Dasar dan Menengah. Jakarta: Badan Pengembangan Sumber Daya Manusia Pendidikan dan Kebudayaan dan Penjaminan Mutu Pendidikan Kementerian Pendidikan dan Kebudayaan. 
Larasati, M., Anita, F., \& Teguh, W. (2018). Pengembangan Modul Berbasis Problem Based Learning Pada Materi Polimer Kelas XII SMK Ma'arif NU 1 Sumpiuh. Jurnal Tadris Kimiya, 3(1), 3241.

Majid, L. (2013). Strategi Pembelajaran. Bandung: PT. Remaja Rosdakarya.

Marsita, R. A., Priatmoko, S., \& Kusuma, E. (2011). Analisis Kesulitan Belajar Kimia siswa SMA dalam Memahami Materi Larutan Penyangga dengan Menggunakan Two-Tier Multiple Choice Diagnostic Instrument. Jurnal Inovasi Pendidikan Kimia, 4(1), 312-520.

Mudlofir, A. \& Fatimatur, R. E. (2017). Desain Pembelajaran Inovatif Dari Teori ke Praktik. Jakarta: Rajawali Pers.

Riduwan. (2016). Skala Pengukuran Variabelvariabel Penelitian. Bandung: Alfabeta.

Rusman. (2012). Model-Model Pembelajaran Mengembangkan Propesionalisme Guru. Jakarta: PT. Raja Grafindo.

Sari \& Lepiyanto, A. (2016). Pengembangan Lembar Kerja Peserta Didik (LKPD) Berbasis Scientific Approach Siswa SMS Kelas X pada Materi Fungi. Bioedukasi, $7(1)$.

Sari, E. dkk. (2016). Pengembangan Lembar Kegiatan Peserta Didik (LKPD) Berbasis Karakter Pada Mata Pelajaran Kimia SMA. Jurnal Edu-Sains, 5(2).

Sukmadinata, N. S. (2006), Metode Penelitian Pendidikan. Bandung: PT. Remaja Rosdakarya.
Tim Penyusun. (2006). Standar Isi dan mata pelajaran kimia SMA/MA. Jakarta: BSNP.

Tim Puslitjaknov. (2008). Metode Penelitian Pengembangan. Jakarta: Depdiknas.

Trianto. (2015). Mendesain Model Pembelajaran Inovativ, Prograsif, dan Kontekstual. Jakarta: Kencana Prenamedia Grup. 